\title{
Theoretical Study and Experimental Validation of Energetic Performances of Photovoltaic/Thermal Air Collector
}

\author{
Khaled Touafek (D), ${ }^{1}$ Abdelkrim Khelifa, ${ }^{1}$ Lyes Boutina, ${ }^{1}$ Ismail Tabet, ${ }^{2}$ and Salim Haddad ${ }^{2}$ \\ ${ }^{1}$ Unité de Recherche Appliquée en Energies Renouvelables (URAER), Centre de Développement des Energies Renouvelables (CDER), \\ 47133 Ghardaïa, Algeria \\ ${ }^{2}$ Université de Skikda, Algeria
}

Correspondence should be addressed to Khaled Touafek; khaledtouafek@yahoo.fr

Received 12 June 2018; Revised 13 September 2018; Accepted 8 October 2018; Published 19 December 2018

Academic Editor: Giulia Grancini

Copyright ( 2018 Khaled Touafek et al. This is an open access article distributed under the Creative Commons Attribution License, which permits unrestricted use, distribution, and reproduction in any medium, provided the original work is properly cited.

This work undertakes both simulation and experimental studies of a new design of a photovoltaic thermal solar air collector $(\mathrm{PV} / \mathrm{T})$. In order to improve the thermal and electrical performances for a specific application, the analytical expressions for thermal parameters and efficiency are derived by developing an energy balance equation for each component of the PV/T air collector. This type of hybrid collector can be applied in the facades of buildings. The electricity and heat produced will satisfy the energy needs of the buildings, while ensuring an aesthetic view of its facades. A typical prototype was designed, constructed, and implemented in the applied research unit on renewable energies in Ghardaia, situated in the south of Algeria. This region has semiarid characteristics. Results obtained by an experimental test are presented and compared to those predicted through simulation. Results include the temperature of each component of the PV/T collector and air temperature at the inlet and outlet of the channel. It has been found that the theoretical results predicted by the developed mathematical model, for instance, outlet temperature, agree with those found through experimental work.

\section{Introduction}

Hybrid photovoltaic thermal (PV/T) collectors convert solar energy both into electrical and thermal energy. This conversion allows firstly the cooling of the solar cells and secondly the exploitation of the resulting heat energy to heat water or space. Applications of hybrid collectors in habitations are beneficial from a space-saving perspective. In fact, instead of separately using photovoltaic modules for electricity and solar thermal energy for heat, hybrid collectors are used for the same surface. In the literature, there are several studies on hybrid sensors applied in the habitat [1-5]. The most important thing in air hybrid sensors is to have the highest air outlet temperature compared to the input air temperature. To have that, several techniques are possible. They can be classified globally in two techniques. The first concerns the use of new coolant materials or the use of phase change materials [6-8]. The second technique is the design of the absorber [9-11]. In this article we are interested in the second technique of optimization of the absorber.
Work on hybrid collectors has been carried out in recent years [12-15].

Farshchimonfared et al. [16] studied a hybrid PV/T air collector related to an air distribution system. The aim was to optimize the channel depth. He found that increases in optimum depth were related to an increase of the collector area. The integration of photovoltaic thermal solar collectors in a building is increasingly becoming an option of first choice. A photovoltaic/thermal integrated collector in a building is able to generate higher energy output per collector unit area compared to conventional solar panels. A hybrid $\mathrm{PV} / \mathrm{T}$ offers the same advantages as a photovoltaic PV collector, but in addition, it offers a look that is more aesthetic than side-by-side photovoltaic modules and solar thermal collectors and generally produces more energy for the same surface area [17]. A PV/T air collector integrated to buildings can be an outer layer that creates a building envelope which is double layered. Due to the heat source-generated sound, their thermal characteristic is different from that of the usual wall [18]. 


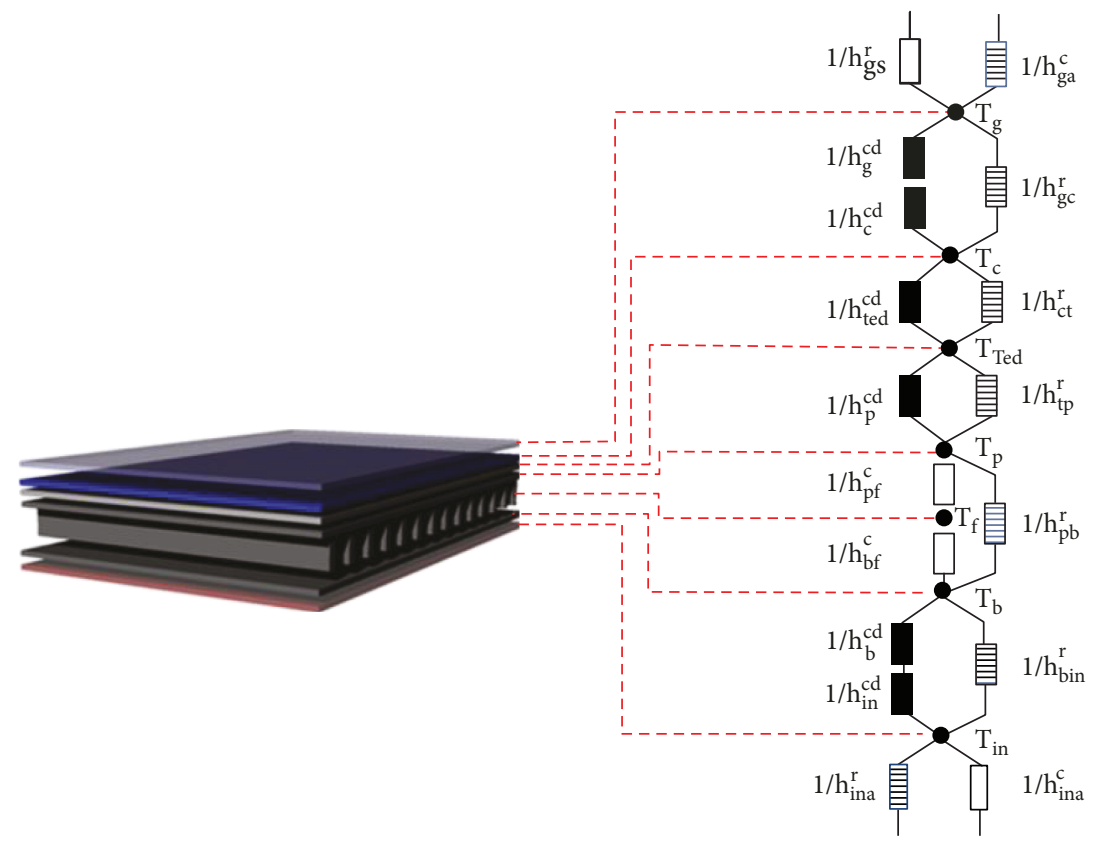

Figure 1: Photovoltaic thermal air collector.

In this paper, numerical simulation and experimental validation of a photovoltaic thermal PV/T solar air collector are conducted. The application of this sensor is conducted in a semiarid climate in the south of Algeria where the very high temperature negatively affects the efficiency of solar cells. The evacuation of the solar cells' heat causes their cooling which allows the photovoltaic sensor to perform well. The modeling of the heat transfer in the PV/T air collector is performed to $1 \mathrm{D}$ for a transitional regime according to a node approach. A numerical code was developed and used to analyze the thermal behavior as well as the thermal, electrical, and global electrical efficiency. Then, an experimental prototype of the $\mathrm{PV} / \mathrm{T}$ air collector was set up. The PV/T air collector temperatures, as well as air inlet and outlet temperatures, were measured over a period of a day during the month of June and November and were compared with $\mathrm{PV} / \mathrm{T}$ air collector model predictions.

\section{Theoretical Study}

The designed photovoltaic/thermal air collector studied in this work is shown in Figure 1. The PV/T air collector is composed of a photovoltaic module which consists of arrays of monocrystalline circular silicon cells covered with highly transmitting glass. These cell arrays are interposed on an adhesive layer made of Tedlar having good thermal conductivity and poor electrical conductivity. The photovoltaic module is to be mounted on a metal plate painted in black to increase the absorption of the incident solar radiation falling upon an absorbing plate equipped with rectangular fins which serve as channels for air circulation. The circulation of the air in the fins collects the generated heat, and a useful amount of thermal energy is extracted by removing hot air from one end of the duct leaving the cold fluid to enter at the other end. The bottom of the sheath is covered with good insulation to minimize heat loss to the ambient temperature.

The thermal energy balance equations for the different nodes of the system is shown in Figure 1.

The heat balance which describes the thermal behavior of the PV/T air collector can be written in the form of first order ordinary differential equations and are given for the following essential elements of the hybrid PV/T air collector:

(1) For glass

$$
\begin{aligned}
M_{g} c_{g} \frac{d T_{g}}{d t}= & q_{g}(t)-h_{g s}^{r} A_{g}\left(T_{g}-T_{s}\right) \\
& -h_{g a}^{c} A_{g}\left(T_{g}-T_{a}\right) \\
& -\left(U_{1}+h_{g c}^{r}\right) A_{g}\left(T_{g}-T_{c}\right),
\end{aligned}
$$

where

$$
\begin{aligned}
q_{g}(t) & =\alpha_{g} I_{g}(t) A_{g}, \\
U_{1} & =\left(\frac{1}{h_{g}^{c d}}+\frac{1}{h_{c}^{c d}}\right)^{-1} .
\end{aligned}
$$

(2) For solar cells

$$
\begin{aligned}
M_{c} c P_{c} \frac{d T_{c}}{d t}= & q_{c}(t)-\left(h_{\mathrm{ted}}^{c d}+h_{c t}^{r}\right) A_{c}\left(T_{c}-T_{\text {ted }}\right) \\
& +\left(U_{1}+h_{g c}^{r}\right) A_{c}\left(T_{g}-T_{c}\right),
\end{aligned}
$$


where

$$
q_{c}(t)=\tau_{g} \alpha_{c}\left(1-\eta_{\mathrm{pv}}\right) I_{g}(t) A_{c}
$$

The solar cell efficiency depends on the cell temperature and is given by [19]

$$
\eta_{\mathrm{pv}}=\eta_{\mathrm{ref}}\left[1-0.0045\left(T_{c}-25\right)\right]
$$

where $\eta_{\text {ref }}$ is the reference efficiency of a solar cell at a solar irradiance of $1000 \mathrm{Wm}^{-2}$ and temperature $T_{\text {ref }}=25^{\circ} \mathrm{C}$.

In this work, $\eta_{\text {ref }}=10 \%$.

(3) For Tedlar layer

$$
\begin{aligned}
M_{\text {ted }} c p_{\text {ted }} \frac{d T_{\text {ted }}}{d t}= & \left(h_{\text {ted }}^{c d}+h_{c t}^{r}\right) A_{t}\left(T_{c}-T_{\text {ted }}\right) \\
& -\left(h_{\text {tp }}^{r}+h_{p}^{c d}\right) R_{\text {tp }} A_{t}\left(T_{\text {ted }}-T_{p}\right)
\end{aligned}
$$

where

$$
R_{\mathrm{tp}}=\frac{A_{\mathrm{tp}}}{A_{c}}
$$

(4) For upper plate with fins

$$
\begin{aligned}
M_{p} c p_{p} \frac{d T_{p}}{d t}= & -\left(h_{p}^{c d}+h_{r \mathrm{tp}}^{r}\right) A_{p} R_{\mathrm{tp}}\left(T_{p}-T_{\mathrm{ted}}\right) \\
& -h_{p f}^{c} A_{p} \eta_{p}\left(T_{p}-T_{f}\right)-h_{p b}^{r} A_{p} R_{\mathrm{bp}}\left(T_{p}-T_{b}\right),
\end{aligned}
$$

where $\eta_{p}$ is the total efficiency of the absorbing upper plate end and $\eta_{f}$ is the fin efficiency $[1,20]$.

$$
\begin{gathered}
\eta_{f}=\frac{\tanh \left(m h_{f}\right)}{\lambda_{f} \delta_{f}}, \\
m=\left(\frac{2 h_{f}}{\lambda_{f} \delta_{f}}\right)^{1 / 2}, \\
\eta_{p}=\frac{A_{c}+A_{f \mathrm{in}} \eta_{f}}{A_{\mathrm{bp}}}, \\
R_{\mathrm{bp}}=\frac{A_{\mathrm{bp}}}{A_{c}}
\end{gathered}
$$

(5) For fluid in the fins

$$
\begin{aligned}
M_{f} c p_{f} \frac{d T f}{d t}= & -c p_{f} \dot{m} \frac{d T_{f}}{w d x}-h_{p f}^{c} A_{f} R_{\mathrm{bp}} \eta_{p}\left(T_{f}-T_{p}\right) \\
& -h_{b f}^{c} A_{f}\left(T_{f}-T_{b}\right) .
\end{aligned}
$$

(6) For lower plate

$$
\begin{aligned}
M_{b} c p_{b} \frac{d T_{b}}{d t}= & h_{b f}^{c} A_{b}\left(T_{f}-T_{b}\right)-h_{p b}^{r} A_{b} R_{\mathrm{bp}}\left(T_{b}-T_{p}\right) \\
& -\left(h_{b \text { in }}^{r}+U_{2}\right) A_{b}\left(T_{b}-T_{\mathrm{in}}\right),
\end{aligned}
$$

where

$$
U_{2}=\left(\frac{1}{h_{\mathrm{in}}^{c d}}+\frac{1}{h_{b}^{c d}}\right)^{-1}
$$

(7) For insulation

$$
\begin{aligned}
M_{\text {in }} c p_{\text {in }} \frac{d T_{\text {in }}}{d t}= & -h_{\text {in } a}^{r} A_{\text {in }}\left(T_{\text {in }}-T_{s}\right)-h_{\text {in } a}^{c} A_{\text {in }}\left(T_{\text {in }}-T_{a}\right) \\
& -\left(h_{b \text { in }}^{r}+U_{4}\right) A_{\text {in }}\left(T_{\text {in }}-T_{b}\right) \\
& +A_{\text {in }}\left(T_{b}-T_{\text {in }}\right) .
\end{aligned}
$$

The temporal variation of the components of the collector of heat is low, thus ( $m c p d T) / d t$ can be ignored. We can safely assume a quasistationary operation of the collector. This simplification of the equation suggests that only solar radiation has a significant effect.

By eliminating $T_{p}$ and $T_{b}$, (11) becomes

$$
\frac{d T_{f}}{d x}+C_{1} T_{f}(x)=C_{2} .
$$

If $C_{1}$ and $C_{2}$ are constants obtained from the performed algebraic calculations, the solution of the equation is

$$
T_{f}(x)=\frac{C_{2}}{A_{1}}+\left(T_{f i}-\frac{C_{2}}{C_{1}}\right) e^{-C_{1} x}
$$

and the outlet temperature of the air is

$$
T_{\text {fout }}=\frac{C_{2}}{C_{1}}+\left(T_{f i}-\frac{C_{2}}{C_{1}}\right) e^{-C_{1} l}
$$

In the above equations, radiation and convective heat transfer coefficients are calculated using the relationships as reported in [21-23].

The wind convection heat-transfer coefficient $h_{i-a}^{\mathrm{c}}$ for the air flowing over the outside surface depends primarily on the wind velocity $v$ and is defined as

$$
h_{i-a}^{c}=5.7+3.8 v \text {. }
$$

The radiation heat transfer coefficient between the glass cover and the sky is given by the following relationship:

$$
h_{g-a}^{r}=\varepsilon_{g} \sigma\left(T_{g}^{2}+T_{s}^{2}\right)\left(T_{g}+T_{s}\right)
$$


The equivalent sky temperature is calculated by the following simple correlation equation:

$$
T_{s}=T_{a}-6
$$

The radiation heat transfer coefficient between the glass cover and the PV panel is given by the following relationship:

$$
h_{g-c}^{r}=\sigma\left(T_{g}^{2}+T_{c}^{2}\right)\left(T_{g}+T_{c}\right)\left(\left(\frac{1}{\varepsilon_{g}}\right)+\left(\frac{1}{\varepsilon_{c}}\right)-1\right) \text {. }
$$

The radiation heat transfer coefficient between the PV panel and the Tedlar layer is given by the following relationship:

$$
h_{c \text {-ted }}^{r}=\sigma\left(T_{c}^{2}+T_{\text {ted }}^{2}\right)\left(T_{c}+T_{\text {ted }}\right)\left(\left(\frac{1}{\varepsilon_{c}}\right)+\left(\frac{1}{\varepsilon_{\text {ted }}}\right)-1\right) \text {. }
$$

The radiation heat transfer coefficient between the upper plate and the Tedlar layer is given by the following relationship:

$$
h_{\text {ted }-p}^{r}=\sigma\left(T_{\text {ted }}^{2}+T_{p}^{2}\right)\left(T_{\text {ted }}+T_{p}\right)\left(\left(\frac{1}{\varepsilon_{p}}\right)+\left(\frac{1}{\varepsilon_{\text {ted }}}\right)-1\right) \text {. }
$$

The radiation heat transfer coefficient between the upper plate and the lower plate is given by the following relationship:

$$
h_{b-p}^{r}=\sigma\left(T_{b}^{2}+T_{p}^{2}\right)\left(T_{b}+T_{p}\right)\left(\left(\frac{1}{\varepsilon_{p}}\right)+\left(\frac{1}{\varepsilon_{b}}\right)-1\right) \text {. }
$$

The radiation heat transfer coefficient between the lower plate and the insulation is given by the following relationship:

$$
h_{b-\text { in }}^{r}=\sigma\left(T_{b}^{2}+T_{\text {in }}^{2}\right)\left(T_{b}+T_{\text {in }}\right)\left(\left(\frac{1}{\varepsilon_{\text {in }}}\right)+\left(\frac{1}{\varepsilon_{b}}\right)-1\right) \text {. }
$$

The conduction heat transfer coefficient is given by the following relationship:

$$
h^{c d}=\frac{\lambda}{e}
$$

The convection heat transfer coefficient of the fluid is given by the following relationship:

$$
\begin{aligned}
h^{c}= & \left(\frac{\lambda}{D_{h}}\right)\left[0.0158 \operatorname{Re}^{0.8}\right. \\
& \left.+(0.00181 \mathrm{Re}+2.92) \exp \left(-\frac{0.0379 x}{D_{h}}\right)\right],
\end{aligned}
$$

where $\operatorname{Re}$ is the Reynolds number

$$
\operatorname{Re}=\frac{\rho D_{h} v}{\mu}
$$

where $D_{h}$ is the hydraulic diameter.

For the rectangular channel

$$
D_{h}=\frac{(2 \times h \times w)}{(h+w)} .
$$

The thermal efficiency of photovoltaic solar collector is calculated by the following relationship $[24,25]$ :

$$
\eta_{\mathrm{th}}=\frac{Q_{u}}{A_{c} I_{t}}=\frac{\dot{m} c p_{f} \int\left(T_{o}-T_{i}\right) d t}{A_{c} \int I_{t} d t} .
$$

The global efficiency of the photovoltaic thermal collector is defined as the sum of all thermal efficiency and electrical efficiency:

$$
\eta_{t}=\eta_{\mathrm{th}}+\eta_{\mathrm{pv}}
$$

\section{Numerical Simulation}

It is obvious from the theoretical model given above that a numerical solution can be calculated for the temperatures $T_{g}, T_{c}, T_{p}, T_{b}, T_{\text {in }}$, and $T_{f}$ as most of the heat transfer coefficients are functions of these temperatures. Therefore, an iterative numerical method based on Runge-Kutta method is used. Indeed, a program was written in Fortran 90 in order to find the values of the temperatures of the PV/T air collector, as well as the values of the thermal and electrical efficiency. This program is summarized by the flowchart presented in Figure 2.

Furthermore, the solar PV/T air collector dimensions and properties of working fluids, as well as the operating conditions, are also needed. System properties and operating conditions which are employed in this study are tabulated in Table 1. The following physical properties of air are assumed to vary linearly with temperature owing to the low temperature range that can be encountered $[20,23]$ :

(1) Dynamic viscosity

$$
\mu_{\text {air }}=(0.0146 T+1.8343) 10^{-5} .
$$

(2) Density

$$
\rho_{\text {air }}=1.1774-0.00359 \times(T-27) .
$$

(3) Thermal conductivity

$$
\lambda_{\text {air }}=0.02624+0.0000758 \times(T-27) \text {. }
$$




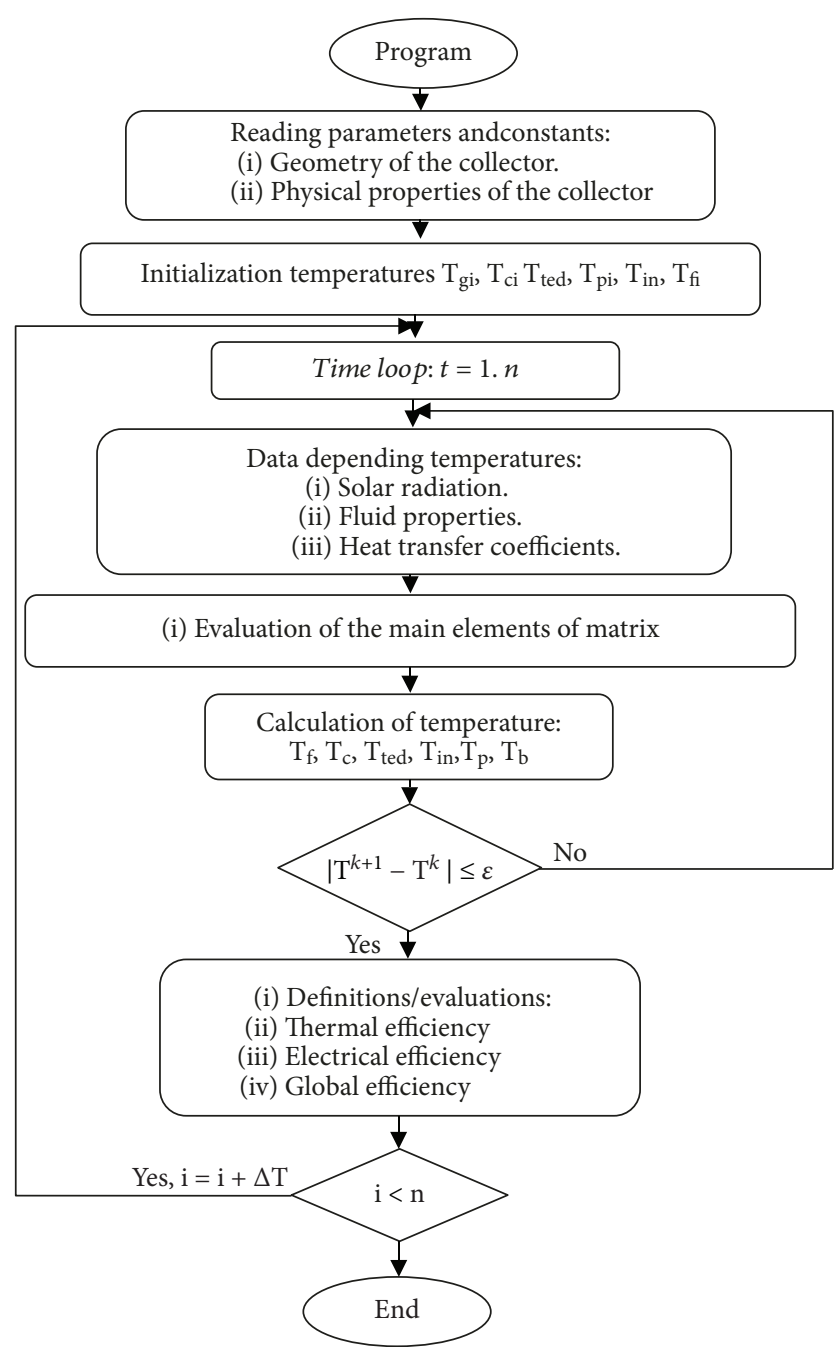

Figure 2: Flowchart for the computer program.

(4) Specific heat

$$
c p_{\text {air }}=[1.0057+0.00066 \times(T-27)] \times 1009 .
$$

Figure 3 presents the hourly temperature variation of essential elements of the hybrid PV/T air collector (glass cover, solar cell, layer in Tedlar, upper absorber plate, lower absorber plate, and insulation). It can be seen from this figure that all temperatures take maximum values in an interval of time ranging between 10 and 14 hours when the solar intensity is also maximal.

Equation (17) was used to calculate the outlet temperature of the hybrid PV/T air collector. The adopted mass flow rate values are equal to $0.01 \mathrm{~kg} / \mathrm{s}, 0.02 \mathrm{~kg} / \mathrm{s}$, and $0.04 \mathrm{~kg} / \mathrm{s}$. Figure 4 displays the hourly variation of the fluid temperature at the outlet for different mass flow rates. It can be observed from this figure that maximal temperatures occurred at $43^{\circ} \mathrm{C}, 38.5^{\circ} \mathrm{C}$, and $34^{\circ} \mathrm{C}$ for the respective mass flow rates of $0.01 \mathrm{~kg} / \mathrm{s}, 0.02 \mathrm{~kg} / \mathrm{s}$, and $0.04 \mathrm{~kg} / \mathrm{s}$. It can be inferred that these temperatures vary with solar radiation intensity.
TABLE 1: Input parameters for numerical calculations.

\begin{tabular}{lccc}
\hline Parameter & Values & Parameter & Values \\
\hline$A_{i}$ & $0.5 \times 1$ & $c p_{c}$ & 700 \\
$h$ & 0.1 & $c p_{\text {ted }}$ & 560 \\
$\delta_{f} \times h_{f} \times l_{f}$ & $0.001 \times 0.05 \times 1$ & $c p_{p}$ & 465 \\
$\tau_{g}$ & 0.90 & $c p_{\text {in }}$ & 880 \\
$\alpha_{g}$ & 0.05 & $\rho_{c}$ & 2700 \\
$\alpha_{c}$ & 0.95 & $\rho_{c}$ & 2330 \\
$\lambda_{g}$ & 1 & $\rho_{p}$ & 7833 \\
$\lambda_{c}$ & 148 & $\rho_{\text {in }}$ & 15 \\
$\lambda_{\text {ted }}$ & 0.033 & $\rho_{\text {ted }}$ & 1200 \\
$\lambda_{\text {in }}$ & 0.041 & $\varepsilon_{g}$ & 0.88 \\
$\lambda_{p}$ & 54 & $\varepsilon_{c}$ & 0.35 \\
$\sigma$ & $5.675 e^{-8}$ & $\varepsilon_{\text {ted }}$ & 0.35 \\
$v_{w}$ & 2 & $\varepsilon_{p}$ & 0.95 \\
$c p_{g}$ & 840 & $\varepsilon_{\text {in }}$ & 0.05 \\
\hline
\end{tabular}

Figure 5 displays the influence of the channel length on the outlet air temperature at constant channel width and mass flow rate being equal to $0.04 \mathrm{~kg} / \mathrm{s}$. It is observed that the outlet air temperature increases with an increase in the channel length. The increased outlet air temperature is due to the increase in the heat exchange area which results in a decrease in air velocity; hence, a low heat transfer coefficient is favorable.

The effect of channel length on thermal, electrical, and global efficiency in the case of a fluid with a mass flow rate equal to $0.04 \mathrm{~kg} / \mathrm{s}$ and a channel depth equal to $0.1 \mathrm{~m}$ is graphed in Figure 6.

It is observed that the thermal efficiency increases with an increase in channel length, while the electrical output decreases with an increase in channel length. The decrease in electrical efficiency is due to the increased PV temperature.

\section{Experimental Validation}

In Figure 7, a prototype of the hybrid photovoltaic thermal air collector is shown. It has a south orientation and is tilted at an angle equal to that of the site where it is installed, in this case $32.49^{\circ}$ in the south of Algeria (Ghardaia) to maximize the intensity of the solar radiation that falls on it. The PV/T air collector was made with a monocrystalline PV module of $40 \mathrm{~W}$, with a $0.5 \mathrm{~m}$ surface area and an air layer of $0.1 \mathrm{~m}$ for collecting hot air. Instrumentation devices are installed to measure the data relating to the thermal and electrical performances of the PV/T air collector.

A type $\mathrm{k}$ thermoelectric device for measuring temperature is used to measure the temperature of each component of the PV/T air collector. Each thermocouple is placed on the surface of each element of the PV/T collector and photovoltaic module. A current and voltage sensor has been installed for measuring the electrical performance. A data- 


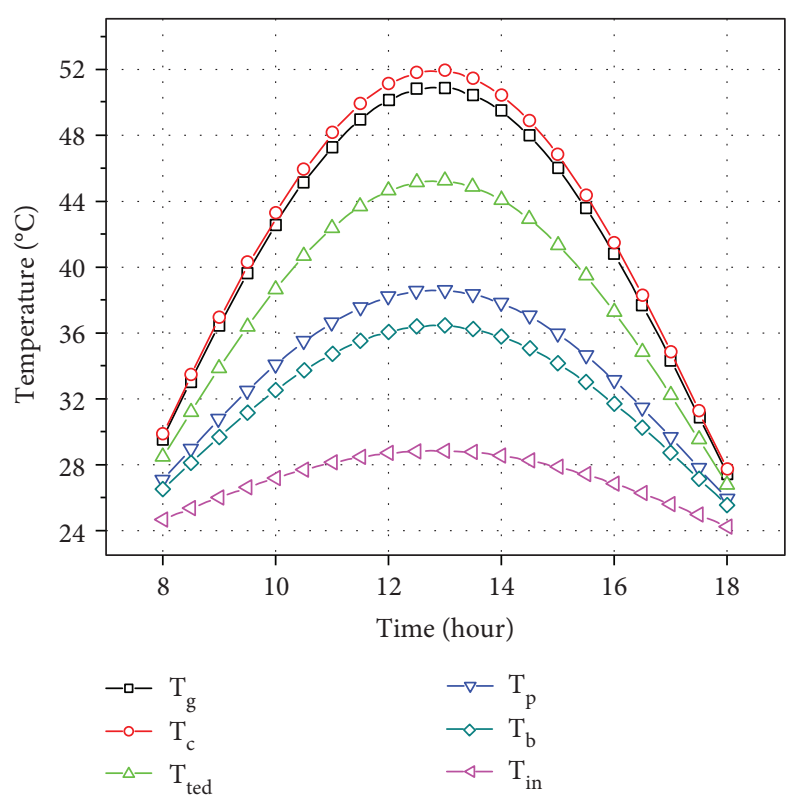

FIGURE 3: Hourly variation of the PV/T air collector element temperature.

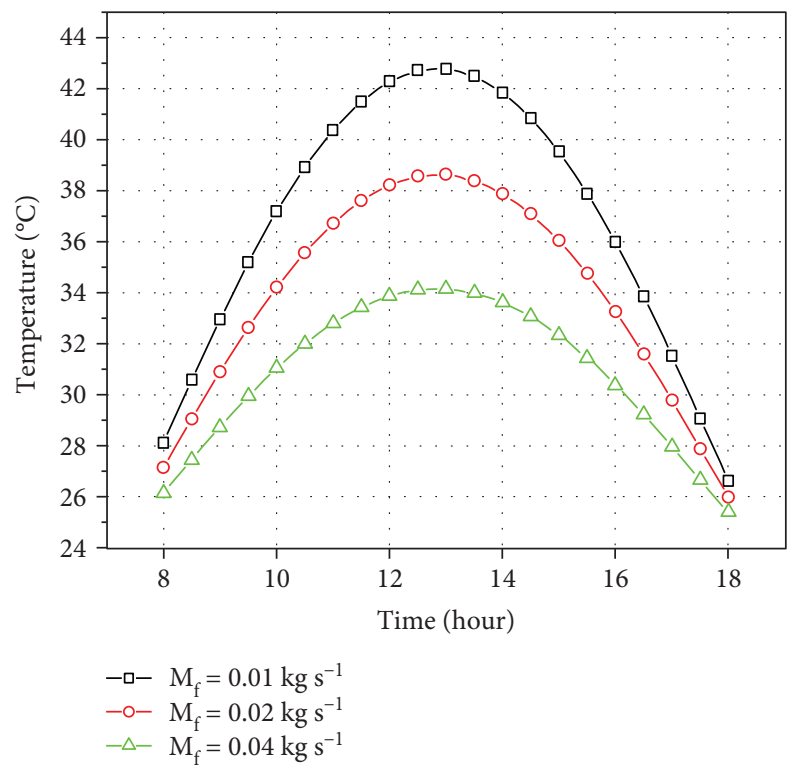

FIgURE 4: Hourly variation of the temperature of the fluid.

acquisition instrument was also connected to record all data on the performance of the PV/T collector.

Test standards such as that of ASHRE are used mainly for the determination of instantaneous thermal efficiency.

Figure 8 displays the hourly variation of the inlet and outlet air temperatures for the day 15 June 2014. Figure 9 displays the variation of temperature elements of the $\mathrm{PV} / \mathrm{T}$ air collector.

It is clearly noticed that the temperature of each constituent element of the PV/T collector reaches it maximum value at noon of the day. This is obviously due to the considerable amount of solar radiation incident on the PV/T at this time,

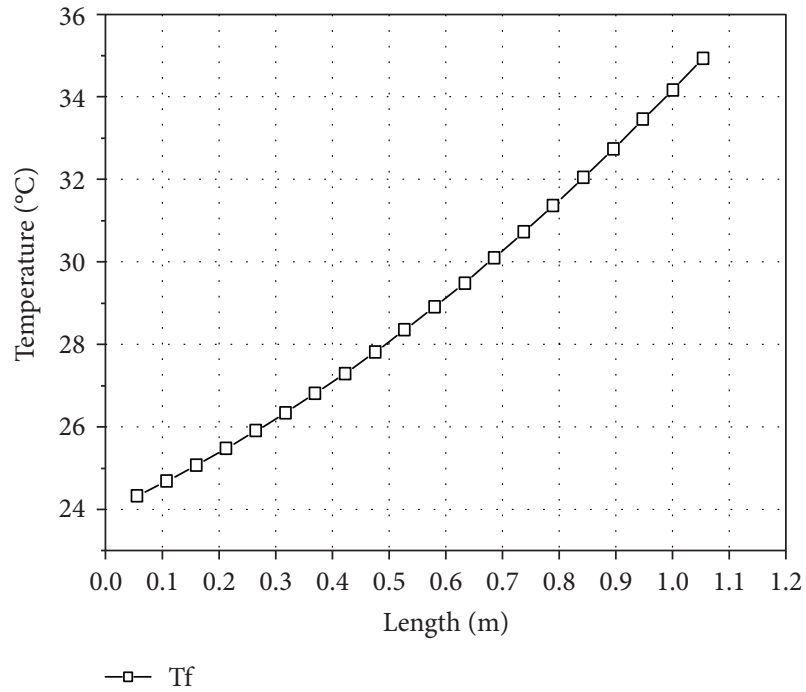

FIgURE 5: Variation of the fluid temperature in the PV/T air collector.

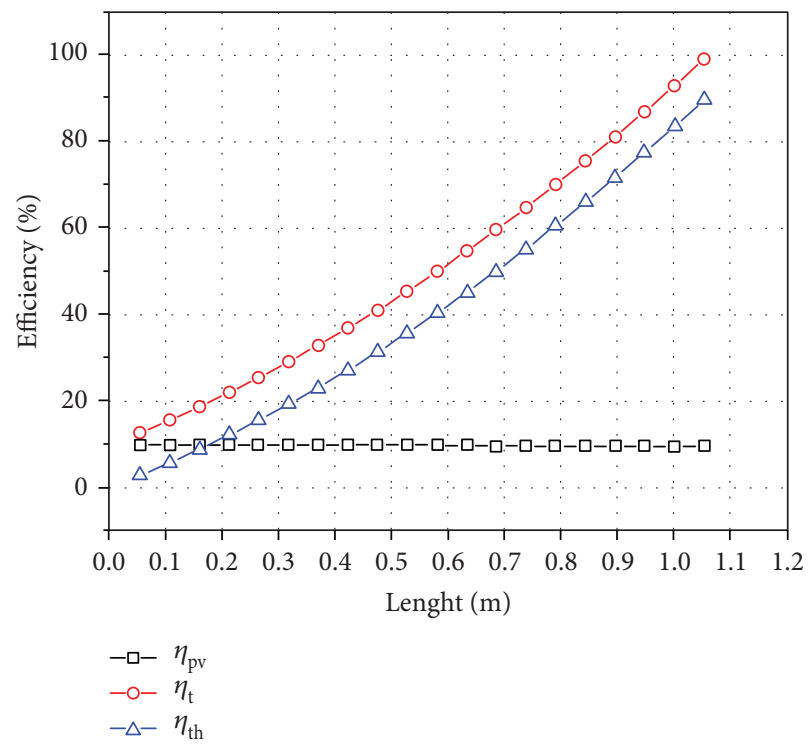

FIGURE 6: Variation of the efficiency of the PV/T air collector.

which results in a high-rate absorption of solar radiation by the PV/T collector. However, it should be noted that each element reaches its maximum value depending on its location in the system and its physical characteristics. The temperatures of the front part of the PV/T collector and the upper plate have higher values when compared to the other elements of the $\mathrm{PV} / \mathrm{T}$ collector. The temperature reaches $60^{\circ} \mathrm{C}$ at noon of the day for the front of the collector and $50^{\circ} \mathrm{C}$ for the upper plate, while the temperature of the other components do not exceed $45^{\circ} \mathrm{C}$ in the same period.

We notice that a temperature difference in the range of about $9^{\circ} \mathrm{C}$ is achieved between the inlet and outlet during the time interval ranging between 10 and 14 hours. This is explained as follows. Because of the increase in the temperature of the upper plate that is bonded to the PV module, 


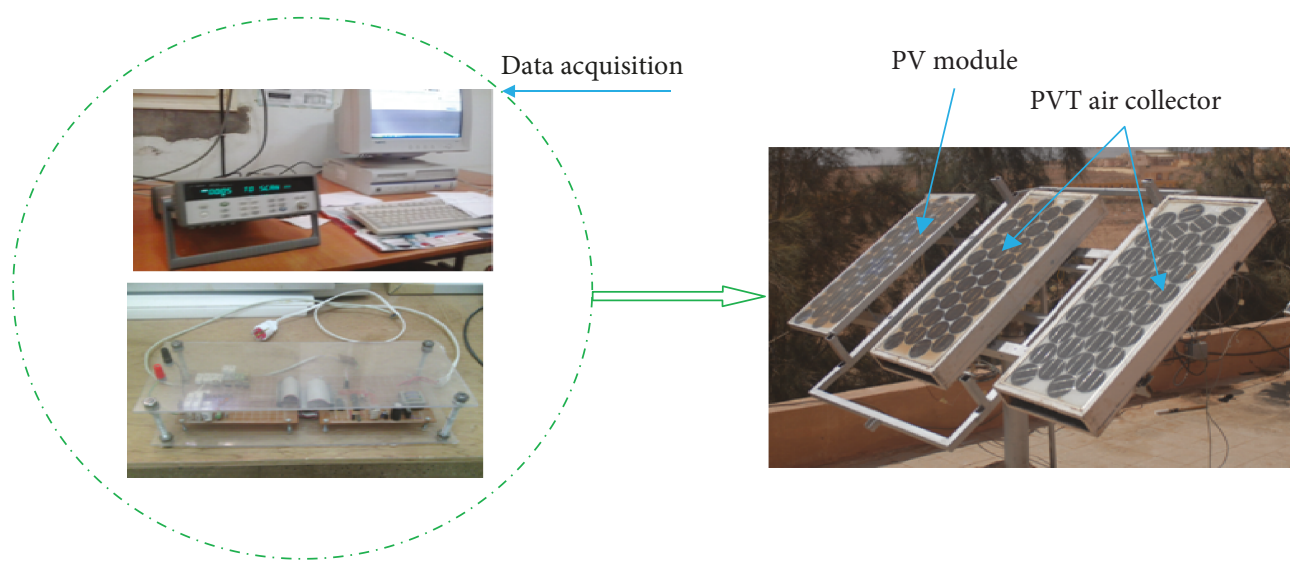

Figure 7: Photo of the experimental prototype.

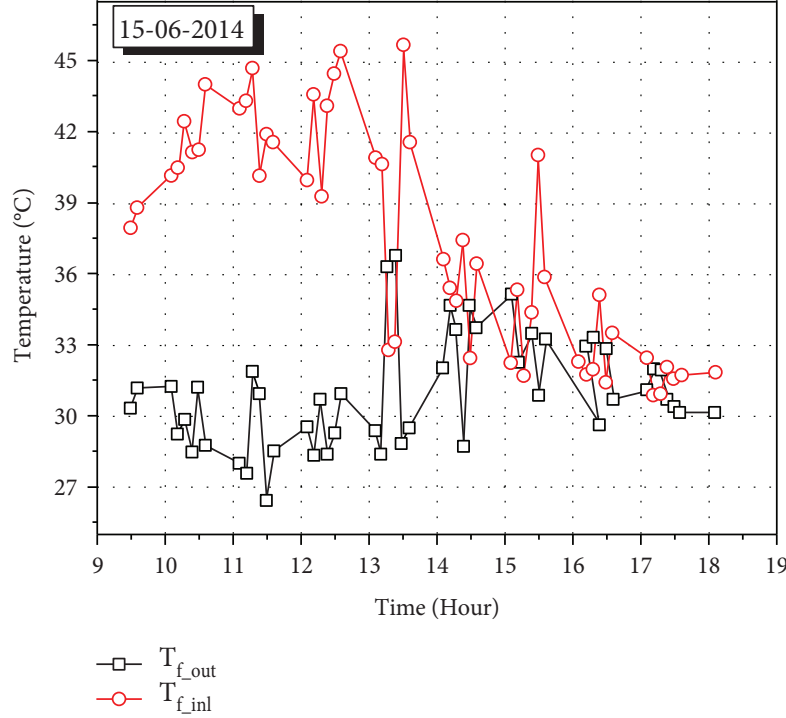

FIgURE 8: Hourly variations of the inlet and outlet air temperatures of the PV/T collector.

the upper plate absorbs the heat generated by the PV module. When the air flows naturally through the channel, a convective exchange occurs between the lower and upper plates with air, and the air takes the heat generated by the two plates which increases their temperature at the outlet of PV/T air collector.

Figure 10 shows the current-voltage characteristic curves obtained by the experimental tests in the morning and evening for the two collectors, that is, the photovoltaic module and the hybrid PV/T air collector. The results showed that for the same surface of the PV and PV/T collector, there is an increase of 7 to $30 \%$ of the current intensity of the hybrid $\mathrm{PV} / \mathrm{T}$ relative to the photovoltaic module.

In Figure 11, the comparison between the results obtained by experimental numerical modeling of the air temperature at the outlet of the $\mathrm{PV} / \mathrm{T}$ air collector is presented. Polynomial interpolation is implemented to approximate the experimental results. The approximation curve is expressed by (35), in the local time (TL) between 8 hours

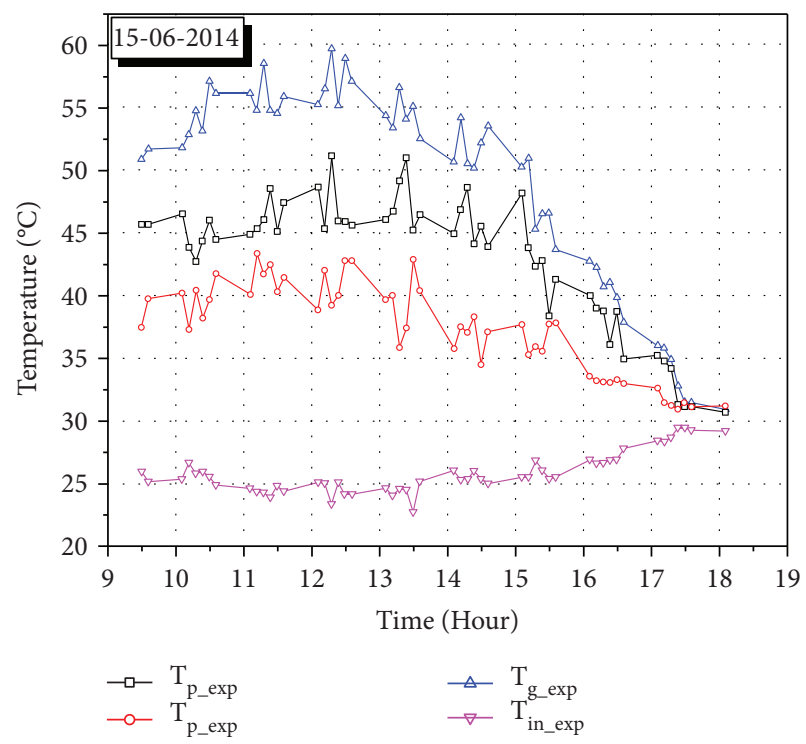

FIgURE 9: Hourly variation of the temperature elements of the $\mathrm{PV} / \mathrm{T}$.

and 17 hours and at the temperature between $25^{\circ} \mathrm{C}$ and $40^{\circ} \mathrm{C}$. It is given by

$$
\begin{aligned}
T_{\text {fout_exp }}= & -659.03457+195.48251 \mathrm{TL} \\
& -20.32914 \mathrm{TL}^{2}+0.94632 \mathrm{TL}^{3} \\
& -0.01688 \mathrm{TL}^{4} .
\end{aligned}
$$

The coefficient of determination $\left(R^{2}\right)$ is the key parameter which serves as the basis of comparison between the simulated and experimental results of the fluid outlet temperatures. The correlation coefficient $\left(R^{2}\right)$ has been evaluated by using the following expression [25]:

$$
R^{2}=1-\frac{\sum_{i}^{k}\left(T_{\text {fout-Exp }}-T_{\text {fout-Theo }}\right)^{2}}{\sum_{i}^{k}\left(T_{\text {fout-Exp }}-T_{\text {fout-mav }}\right)^{2}} .
$$




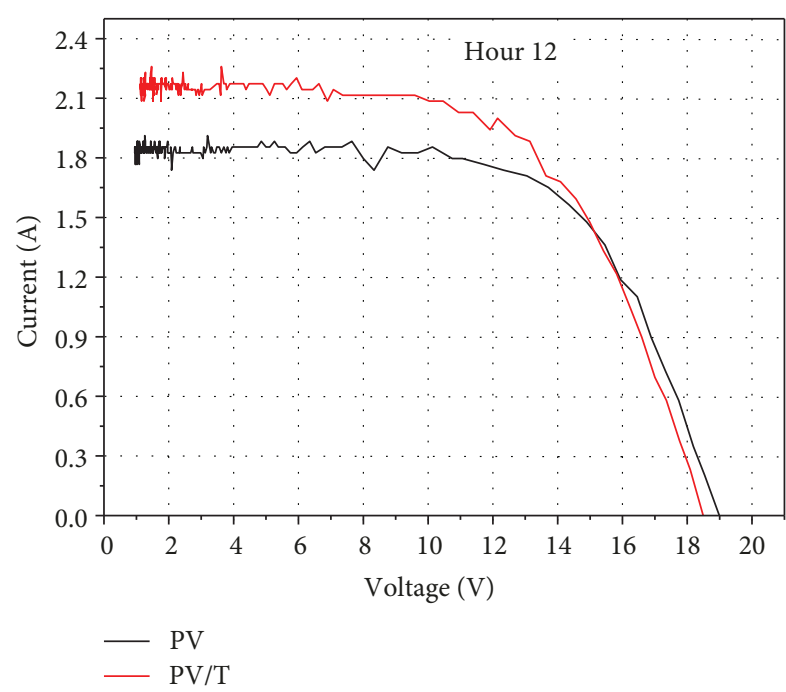

FIGURE 10: Current-voltage characteristic curves of the PV/T air collector and PV module.

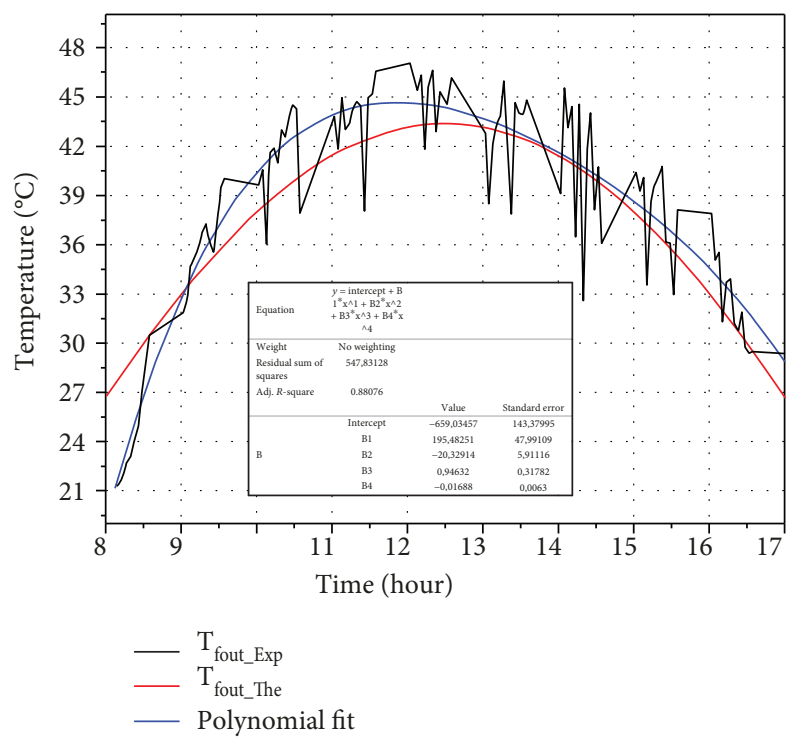

FIGURE 11: Validation of the mathematical model.

The correlation coefficient $\left(R^{2}\right)$ is an indicator for judging the quality of a linear regression, either single or multiple, at a value between 0 and 1 . We found that the $R^{2}$ value is equal to 0.7 , in we find this value acceptable.

We did not study the effect of pressure on electrical and thermal efficiencies. We consider that the temperature is too low for there to be an influence of the pressure on the heat transfer and consequently on the efficiency of the collector.

\section{Conclusion}

In this work, a hybrid PV/T system was investigated, modeled, constructed, and tested. It was found that by combining a PV module with an air collector, the electrical performances are noticeably enhanced. The resulting thermal energy can be exploited to achieve thermal comfort in a building. A mathematical model based on energy balance was developed. Simulation results of this model obtained by using FORTRAN 90 programming language are plotted. The temperatures in the inlet and outlet are monitored and recorded. It was found that the temperature at outlet is higher than the temperature at the inlet, which suggests that a heat exchange has taken place and this is the reason for the improvement of the PV module performances.

The results found through simulation were compared to those found experimentally. Their comparison does show good agreement. This agreement is more pronounced in the case of the inlet and outlet fluid temperatures.

In conclusion, the combination of the PV module with the thermal collector would enhance the electrical performances of the PV module and the resulting thermal energy can be used for other purposes, for instance, to achieve thermal comfort in a building when this combination is wall integrated. In other applications, when water is used instead of air, the heated water can be used for sanitary purposes.

As a future work to further improve the performances of such systems, the PV module is to be replaced by a highefficiency PV module and a reflector is used to concentrate solar radiation upon it.

\section{Nomenclature}

A: $\quad$ Surface $\left(\mathrm{m}^{2}\right)$

$C_{p}:$ Specific heat $\left(\mathrm{J} \mathrm{kg}^{-1} \mathrm{k}^{-1}\right)$

$D_{h}$ : Hydraulic diameter $(\mathrm{m})$

e: Thickness (m)

$h^{c}$ : Convective-exchange coefficient $\left(\mathrm{W} \mathrm{m}^{-2} \mathrm{k}^{-1}\right)$

$h^{r}$ : Radiative-exchange coefficient $\left(\mathrm{W} \mathrm{m}^{-2} \mathrm{k}^{-1}\right)$

$h$ : Channel depth (m)

I: $\quad$ Solar intensity $\left(\mathrm{W} \mathrm{m}^{-2}\right)$

$l: \quad$ Length of the collector $(\mathrm{m})$

$\dot{m}$ : Mass flow $\left(\mathrm{kg} \cdot \mathrm{s}^{-1}\right)$

$M:$ Mass (kg)

$n: \quad$ Number of fins

$R:$ Area ratio

Re: Reynolds number

q: Heat flow (W)

$P$ : $\quad$ Power $(\mathrm{W})$

$t$ : Time (s)

$\mathrm{Tl}$ : Local time (hour)

T: $\quad$ Temperature $\left({ }^{\circ} \mathrm{C}\right)$

$v: \quad$ Speed $\left(\mathrm{m} \mathrm{s}^{-1}\right)$

$w$ : Width of the collector (m)

$U:$ Heat transfer coefficient $\left(\mathrm{W} \mathrm{m}^{-2} \mathrm{k}^{-1}\right)$

$x$ : Distance $(\mathrm{m})$.

\section{Greek Symbols}

$\alpha$ : Absorbance

$\delta$ : Thickness of fin (m)

$\varepsilon$ : Emissivity

$\eta$ : Efficiency

$\lambda$ : Thermal conductivity $\left(\mathrm{W} \mathrm{m}^{-1} \mathrm{k}^{-1}\right)$

$\rho$ : Density $\left(\mathrm{kg} \mathrm{m}^{-3}\right)$ 
$\mu$ : Dynamic viscosity $\left(\mathrm{kg} \cdot \mathrm{m}^{-1} \mathrm{~s}^{-1}\right)$

$\sigma$ : Stefane-Boltzmann constant $\left(\mathrm{W} \mathrm{m}^{-2} \mathrm{~K}^{-4}\right)$

$\tau$ : Transmittance

$\zeta$ : Convergence criterion.

\section{Subscripts and Abbreviations}

a: Ambient

$b$ : Lower plate

bp: Bottom surface of absorber plate

c: $\quad$ Solar cell

$f$ : $\quad$ Fluid

inl: Inlet

g: $\quad$ Glass cover

in: Insulator

p: $\quad$ Upper plate

pv: Electric

out: Outlet

s: $\quad$ Sky

ted: Tedlar

Exp: Experimental

$t: \quad$ Total

th: Thermal

tp: Top surface of absorber plate

Theo: Theory

mav: Mean value.

\section{Data Availability}

All data used in this work is included in the paper.

\section{Conflicts of Interest}

The authors declare that there is no conflict of interest regarding the publication of this paper. This research was performed as part of the requirements during the employment of the authors at the Unit of Applied Research in Renewable Energy (URAER)

\section{References}

[1] Z. B. Liu, L. Zhang, Y. Q. Luo, Y. L. Zhang, and Z. H. Wu, "Performance evaluation of a photovoltaic thermal-compound thermoelectric ventilator system," Energy and Buildings, vol. 167, pp. 23-29, 2018.

[2] D. Gürlich, A. Dalibard, and U. Eicker, "Photovoltaic-thermal hybrid collector performance for direct trigeneration in a European building retrofit case study," Energy and Buildings, vol. 152, pp. 701-717, 2017.

[3] M. Fiorentini, P. Cooper, and Z. Ma, "Development and optimization of an innovative HVAC system with integrated PVT and PCM thermal storage for a net-zero energy retrofitted house," Energy and Buildings, vol. 94, pp. 21-32, 2015.

[4] C. Lamnatou and D. Chemisana, "Photovoltaic/thermal (PVT) systems: a review with emphasis on environmental issues," Renewable Energy, vol. 105, pp. 270-287, 2017.

[5] M. Piratheepan and T. N. Anderson, "Performance of a building integrated photovoltaic/thermal concentrator, for facade applications," Solar Energy, vol. 153, pp. 562-573, 2017.
[6] M. Song, F. Niu, N. Mao, Y. Hu, and S. Deng, "Review on building energy performance improvement using phase change materials," Energy and Buildings, vol. 158, pp. 776-793, 2018.

[7] D. Su, Y. Jia, Y. Lin, and G. Fang, "Maximizing the energy output of a photovoltaic-thermal solar collector incorporating phase change materials," Energy and Buildings, vol. 153, pp. 382-391, 2017.

[8] W. Lin, Z. Ma, P. Cooper, M. I. Sohel, and L. Yang, "Thermal performance investigation and optimization of buildings with integrated phase change materials and solar photovoltaic thermal collectors," Energy and Buildings, vol. 116, pp. 562-573, 2016.

[9] K. Touafek, M. Haddadi, and A. Malek, "Design and modeling of a photovoltaic thermal collector for domestic air heating and electricity production," Energy and Buildings, vol. 59, pp. 21-28, 2013.

[10] M. Alobaid, B. Hughes, J. K. Calautit, D. O'Connor, and A. Heyes, "A review of solar driven absorption cooling with photovoltaic thermal systems," Renewable and Sustainable Energy Reviews, vol. 76, pp. 728-742, 2017.

[11] M. Hosseinzadeh, A. Salari, M. Sardarabadi, and M. Passandideh-Fard, "Optimization and parametric analysis of a nanofluid based photovoltaic thermal system: 3D numerical model with experimental validation," Energy Conversion and Management, vol. 160, no. 15, pp. 93-108, 2018.

[12] J. F. Chen, L. Zhang, and Y. J. Dai, "Performance analysis and multi-objective optimization of a hybrid photovoltaic/thermal collector for domestic hot water application," Energy, vol. 143, pp. 500-516, 2018.

[13] L. Sahota and G. N. Tiwari, "Review on series connected photovoltaic thermal (PVT) systems: analytical and experimental studies," Solar Energy, vol. 150, pp. 96-127, 2017.

[14] E. Sakellariou and P. Axaopoulos, "Simulation and experimental performance analysis of a modified PV panel to a PVT collector," Solar Energy, vol. 155, pp. 715-726, 2017.

[15] D. B. Singh, "Improving the performance of single slope solar still by including N identical PVT collectors," Applied Thermal Engineering, vol. 131, pp. 167-179, 2018.

[16] M. Farshchimonfared, J. I. Bilbao, and A. B. Sproul, "Channel depth, air mass flow rate and air distribution duct diameter optimization of photovoltaic thermal (PV/T) air collectors linked to residential buildings," Renewable Energy, vol. 76, pp. 27-35, 2015.

[17] V. Delisle and M. Kummert, "A novel approach to compare building-integrated photovoltaics/thermal air collectors to side-by-side PV modules and solar thermal collectors," Solar Energy, vol. 100, pp. 50-65, 2014.

[18] J.-H. Kim and J.-T. Kim, "A simulation study of air-type building-integrated photovoltaic-thermal system," Energy Procedia, vol. 30, pp. 1016-1024, 2012.

[19] A. K. Athienitis, J. Bambara, B. O’Neill, and J. Faille, “A prototype photovoltaic/thermal system integrated with transpired collector," Solar Energy, vol. 85, no. 1, pp. 139-153, 2011.

[20] M. Gholampour and M. Ameri, "Energy and exergy study of effective parameters on performance of photovoltaic/thermal natural air collectors," Journal of Solar Energy Engineering, vol. 136, no. 3, article 031001, 2014.

[21] L. M. Candanedo, A. Athienitis, and K.-W. Park, "Convective heat transfer coefficients in a building integrated photovoltaic/ thermal system," Journal of Solar Energy Engineering, vol. 133, no. 2 , article $021002,2011$. 
[22] J. A. Duffie and W. A. Beckman, Solar Engineering of Thermal Processes, JohnWiley \& Sons, New York, NY, USA, 2nd edition, 1991.

[23] E. M. Ali Alfegi, K. Sopian, M. Y. H. Othman, and B. B. Yatim, "Transient mathematical model of both side single pass photovoltaic thermal air collector," ARPN Journal of Engineering and Applied Sciences, vol. 2, p. 5, 2007.

[24] K. Touafek, M. Haddadi, and A. Malek, "Experimental study on a new hybrid photovoltaic thermal collector," Applied Solar Energy, vol. 45, no. 3, pp. 181-186, 2009.

[25] I. Tabet, K. Touafek, N. Bellel, N. Bouarroudj, A. Khelifa, and M. Adouane, "Optimization of angle of inclination of the hybrid photovoltaic-thermal solar collector using particle swarm optimization algorithm," Journal of Renewable and Sustainable Energy, vol. 6, no. 5, article 053116, 2014. 

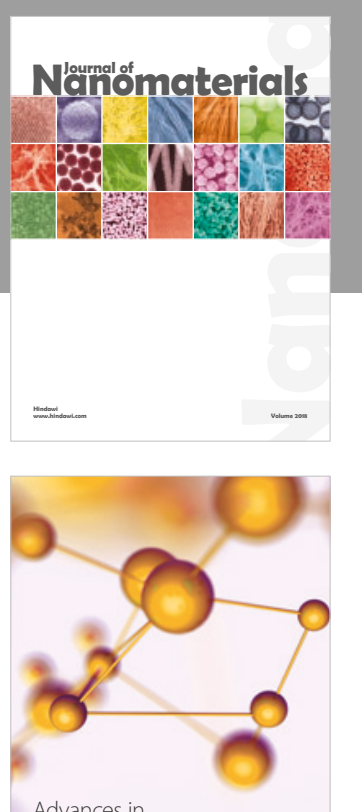

Physical Chemistry
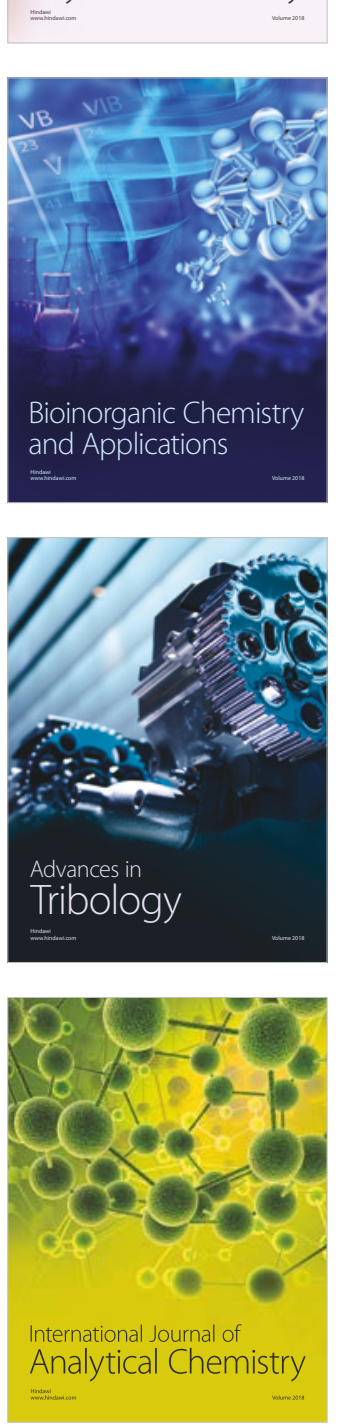

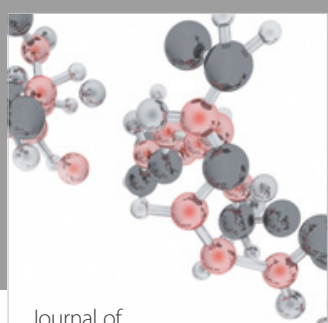

Analytical Methods

in Chemistry

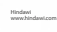

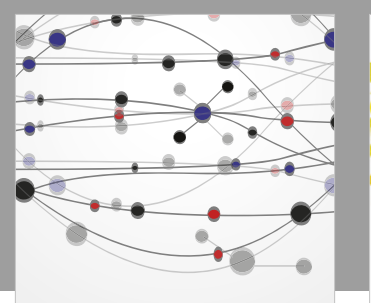

The Scientific World Journal

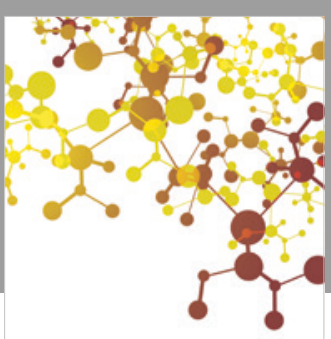

Journal of

Applied Chemistry
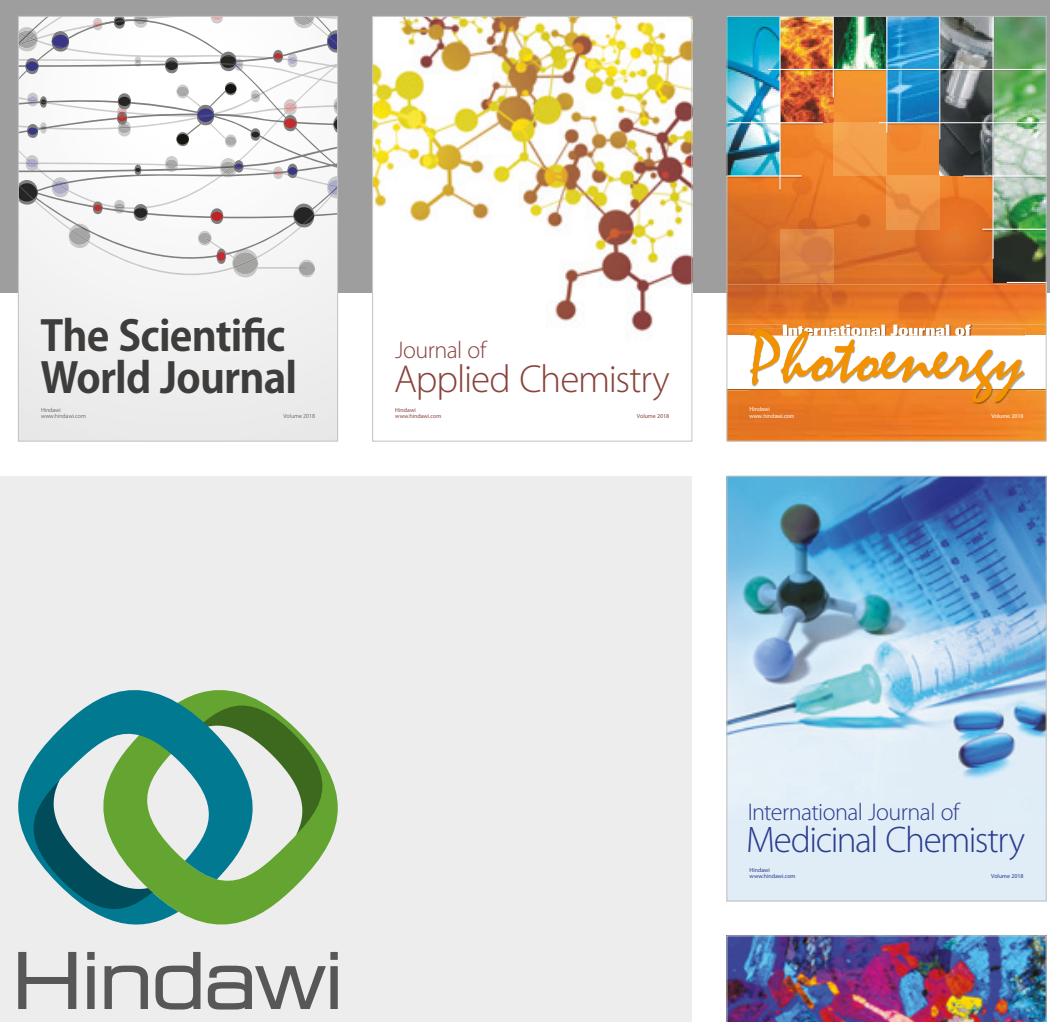

Submit your manuscripts at

www.hindawi.com
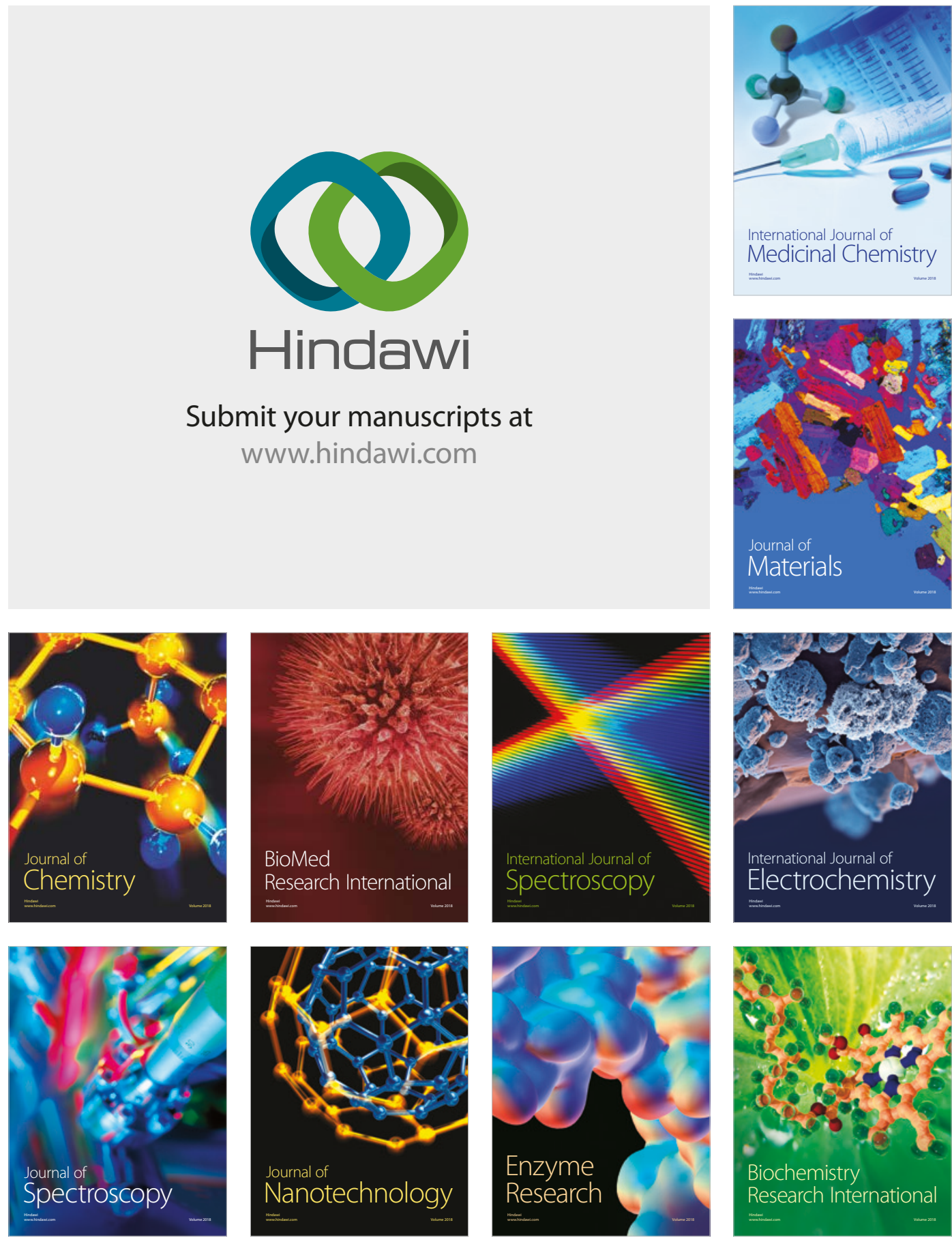
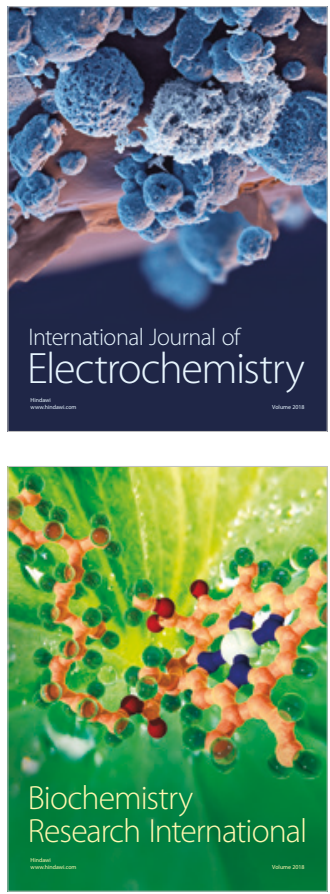